\title{
The Impact of Internal Corporate Governance on the Timeliness of Financial Reports of Jordanian Firms: Evidence using Audit and Management Report Lags
}

\author{
Khaldoon Ahmad Al Daoud \\ Ku Nor Izah Ku Ismail \\ Nor Asma Lode
}

School of Accountancy, College of Business, Universiti Utara Malaysia, 06010 Sintok, Kedah, Malaysia

Email: Khaldoon_Joh@yahoo.com

\section{Doi:10.5901/mjss.2015.v6n1p430}

\section{Abstract}

This study explores the influence of board independence, board size, CEO duality, board diligence, board financial expertise and presence of audit committee as well as the type of sector on the timeliness of financial reports among selected Jordanian companies. The timeliness of the financial reports is measured by audit report lag (ARL) and management report lag (MRL). This study covers 112 firms listed on the Amman Stock Exchange for the years 2011 and 2012. The results of the ARL model indicate that companies that have members of board who are independent from management take a significantly shorter time to prepare and issue their financial reports. The results indicate that companies with greater number of board of directors are related with a higher audit report lag. The results also show that companies that separated the CEO and chairman's roles are quicker in publishing financial reports than companies combining the roles of CEO and chairman. In addition, boards of directors with more meetings make the audit report lag shorter. The findings also support that argument that the existence of an audit committee could resolve the information asymmetry between management and external auditors that, in turn, would lead to reduced audit report lag and management report lag. However, the results of the MRL model show that management report lag is related positively to large board size and board diligence and negatively to the existence of audit committee. This study concludes that the good structures of corporate governance play a key role in improving the quality of timeliness of financial reports.

Keywords: Timeliness of financial reports, audit and management report lag, Jordanian firms.

\section{Introduction}

Timeliness of financial reports has been acknowledged as one of the qualitative characteristics of the basic objective of financial reports (APB, 1970; AICPA, 1973; FASB, 1979). Empirical research regarding the topic evinces the importance of financial reporting in corporate governance as financial reporting is associated with transparency (Abdullah, 2006), and value of firms (Chambers \& Penman, 1984; Haw, Qi, \& Wu, 2000; Al-Khouri \& Balqasem, 2006), as well as the effectiveness of financial markets (Aktas \& Kargin, 2011). According to Owosu-Ansah (2000), the timeliness of financial reports is a significant mechanism to minimize insider trading, leaks and rumors among emerging capital markets. Timeliness is also an important characteristic of the usefulness of accounting information (Ku Ismail \& Chandler, 2004) and regarded as one measure of audit quality (Leventis, Weetman, \& Caramanis, 2005). Financial report timeliness has been considered by accounting standards-setting entities all over the globe to be the top crucial quality of financial information as the delay in its publication may lead to costs to both decision makers and relevant users (Brown, Dobbie, \& Jackson, 2009).

Timeliness is a topic that has been increasingly addressed by accounting regulators, organizations and authorities around the world. For instance, the United States Securities and Exchange Commission (SEC), the New York Stock Exchange (NYSE), and NASDAQ have all established requirements and recommendations concerning the timeliness of published financial reporting (Abdelsalam \& Street, 2007). Moreover, the significance of financial reporting is also stressed by the Financial Accounting Standards Board (FASB, 1980) in the Statement of Financial Accounting Concepts No.2. The Statement notes that financial reporting should furnish information on a timely basis to potential investors, creditors, and other users who need to make rational investment decisions at an appropriate time in a fiscal year. The accounting profession and the SEC have stressed requirements for timeliness of financial reports, through statement No. 4 of the 
Accounting Principles Board (1970) that provides the definition of timeliness of financial reports as one of the primary aims of accounting (Givoly \& Palmon, 1982).

\section{Overview of Timeliness of Financial Reports in Emerging Capital Markets}

Financial information that is reliable and timely is required to obtain and retain the confidence of investors. In the context of emerging capital markets, the audited financial statements provided in annual reports are deemed to be the sole reliable basis of financial information among capital markets. However, a gap exists between the end of the financial year and the audited financial reports publication and minimizing this gap would enhance the efficiency of capital markets. Importantly, regulators must determine the reasons behind this gap prior to legislating in order to mitigate delay (Leventis et al., 2005). Errunza and Losq (1985) contended that firms in emerging capital markets have a tendency to report more slowly in comparison to those in developed markets. In Jordan, this lack of timeliness exists despite the fact that the securities commission has developed protection of investors and created sanctions for delayed reports in its capital markets. In a World Bank and International Monetary Fund (IMF) assessment in 2004, Jordanian firms financial reporting still lagged behind indicating that financial reporting for some listed firms of periodic disclosure was still a problem (Berg \& Nenova, 2004). This is a critical indication for many reasons; the non-provision of the results of business to shareholders, the ambiguity concerning developments detrimental to shareholders, opportunity for officials to manipulate the firm reports, and the inability to hold the Governing Council accountable in cases of shareholder's damage.

Delayed financial reporting is the cause of disagreements in domestic as well as international levels. At the latter level, several researchers have criticized audit report lag as being responsible for the delay of financial reporting and lead to lower quality of financial reports (Al-Ajmi, 2008; Leventis et al., 2005; Afify, 2009; Brown et al., 2009; Mohamad-Nor, Shafie \& Wan-Hussin, 2010).). Another disagreement concerning timeliness of financial reports is the opportunity for manipulation in the final release of financial statements by firm management. In other words, management may decide to abuse the financial report release by postponing its publication.

\section{Corporate Governance and Timeliness of Financial Reports}

Corporate governance has permeated the globe and has a key role in promoting the timeliness of financial reports (Sharar, 2007). Following the financial crisis that negatively impacted Jordan in 2008, attempts have been made to regain public confidence that had been considerably minimized due to the crisis. As a result, a dire need is present for the industry to enhance structures of corporate governance. For instance, the Organization for Economic Cooperation and Development (OECD) and the Jordanian Forum for Economic Development (JFED) supported by the Global Corporate Governance Forum (GCGF) and several other organizations could play crucial roles. According to Al-Tahat (2010), the primary aim of these organizations is to improve the role of Jordanian firms in their adoption and establishment of laws of conduct for firms and effective corporate governance principles. More importantly, mechanisms of corporate governance will improve monitoring of management and minimize mismanagement and erroneous reporting and financial reporting process delays (Afify, 2009). In other words, as stated by Abdelsalam and Street (2007), a significant relationship exists between corporate governance characteristics and timeliness of financial reports.

Effective corporate governance should be viewed as a way to reduce agency conflict particularly when that governance considers the best interests of all shareholders. This is the reason why Afify (2009) contended that the existence of corporate governance structures should improve management observation of rules and to minimize the occurrence of management misbehavior, erroneous reporting and financial reporting delays. Hence, creating effective corporate governance should enhance internal control and mitigate business risks, which would influence shorter audit delay. Similarly, Hashim and Rahman (2010) demonstrated that corporate governance is a tool that safeguards from selfserving behavior of management. In this regard, Peasnell et al. (2005) supported agency theory by showing that the board contributes to the integrity of financial statements.

The necessity to examine the relationship between firms' governance and the timeliness of financial reports has been demonstrated by the current interest of the Jordanian government in corporate governance particularly following The Companies Law No. 22 of 1997. Such law states that it is mandatory for Jordanian firms in the Amman Stock Exchange (ASE) to form boards and committees to employ the mechanisms of corporate governance. Also, Securities Law passed in 2002 mandates that Jordanian public firms apply corporate governance to facilitate financial statements transparency and accountability and to monitor the behavior of directors to prevent financial reports manipulation through delay of those reports. Moreover, several authors have said that the existence of corporate governance systems can improve the monitoring of management and mitigate management incidence or erroneous reporting and financial reports 
delays (e.g., Afify, 2009; Shukeria \& Nelson, 2011). It can, therefore, be stated that effective corporate governance can enhance internal controls, confine business risks and bring about shorter audit delay and improve timeliness of financial reports.

In the context of Jordanian firms, timeliness of financial reports is a pivotal issue owing to the potential impact of such a reporting lag on several relevant parties. The present study is therefore justified owing to the present disagreement concerning timeliness of financial reports and its relationship with audit report lag and management report lag, and the relevant stakeholders impacted by the delay in financial reporting. Studies dedicated to the financial reports in Jordan are few and far between, and this deficiency motivated the researchers to examine the topic and to contribute to literature. The study conducts an assessment of whether financial reports disclosure is successful in providing stakeholders with ongoing and timely information that facilitates the development of Jordan's financial markets.

\section{Hypotheses Development}

\subsection{Board Characteristics}

A board of directors has been acknowledged widely as a crucial mechanism of corporate governance that balances the interests of managers and the stakeholders of the firm. The primary objective of adopting mechanisms of corporate governance is realizing alignment defined by potential agency-related problems and the issue of free-riding that makes it challenging for a stakeholder to monitor management costs (Sanda, Garba, \& Mikailu, 2011). Also, the code of corporate governance in Jordan mandates that Jordanian firms employ the best corporate governance practices to guarantee superior monitoring. A board of directors is the core institution in a firm's internal governance practices. It plays a key role in the governance of firms and institutions and is responsible of controlling managers' behavior and ensuring that the board is aligned with all stakeholders' interests (Dimitropoulos \& Asteriou, 2010). The characteristics of the board are significant determinants of the timeliness of a firm's annual reports (Wu, 2008).

\subsubsection{Board Independence}

Fama and Jensen (1983) stated that outside members of the board of directors could increase firm value by providing monitoring services and experiences and are considered to be the protectors of the interests of shareholders via their control and monitoring. Meanwhile, according to Afify (2009), the independence of a board of directions is related to its composition and the board is expected to be more independent as external directors increase in proportion to nonindependent directors. Also, Givoly and Palmon (1982) revealed that management has ample motivation to practice discretion over the timeliness of financial reports. A higher number of independent directors on the board reflects efficient monitoring of management (Afify, 2009). An independent board possessing financial expertise is invaluable in overseeing the financial reporting practices of the company (Agrawal \& Chadha, 2005). Similarly, Cheng and Courtenay (2006) demonstrated that a higher percentage of independent directors on the board is linked with higher degrees of voluntary disclosure.

In a similar vein, Afify (2009) revealed the significant relationship between an independent board and the lag in audit reporting and indicated that the monitoring role of independent board could positively influence the quality of financial disclosure and timeliness of financial reports, along with providing an effective and efficient audit, and thus, it mitigates against a large lag in an audit report. Abdelsalam and El-Masry (2008) also showed that board independence related positively to the timeliness of financial Internet reporting. Moreover, Beasley and Petroni (2001) contended that independent directors were associated with high-quality auditing and that a greater proportion of independent directors on the board resulted in the use of more specialized major auditors compared to company counterparts that had with fewer independent directors. The implication is that having more independent members of the board results in timelier financial reporting. Furthermore, according to Klein (2002), boards that are structured to be more independent of the CEO are more effective and efficient in their oversight of the corporate process of financial accounting. Companies with a larger percentage of outside directors have a greater tendency to issue earnings more frequent and timely forecasts (Ajinkya, Bhorjraj, \& Sengupta, 2005). On the other hand, Wu (2008) stated that increased independent directors on a board is linked to reduced report lag, and this result has been attributed to the time spent in confirming firm events. On a final note, Braswell et al. (2012) claimed that independent boards indicate strong governance mechanisms, and such boards have a higher tendency to motivate management through their monitoring. Thus, we hypothesize that:

$\mathrm{H1}$ : Board independence is associated positively with the timeliness of financial reports. 


\subsubsection{Board Size}

Corporate governance mechanisms are considered to be a stepping-stone to resolving diverse types of agency-related problems. The board's monitoring role plays a crucial role in corporate governance, in which its effectiveness and efficiency are reflected through its composition, size and independence (John \& Senbet, 1998). The optimal size for a board of directors is an issue for a company, with a big-sized board facing coordination challenges and a small-sized one being appropriate for coordination but lacking necessary competence and experience (Matoussi \& Chakroun, 2007). In this regard, Lipton and Lorch (1992) claimed that small boards facilitate improved performance, with the optimal number of members being seven or eight - as this size board would be a challenge for the CEO to control. According to them, large-sized boards could result in meaningless discussions coupled with time-consuming and difficult realization of outcomes and a lack of cohesion. The Jordanian Corporate Governance Code establishes that the board size should neither be too large or too small but should be appropriate in size to enable active and effective member participation and that the members should be capable of effectively carrying out their duties. The Code also mentions that the board member size is left to the discretion of the firm but that size should not be less than 5 and not more than 13 (Abed, Attar, \& Suwaidan, 2012).

Board size has been the topic of discussion in several works over the years. According to agency theory, larger boards are positively related with quality financial reporting. Peasnell et al. (2005) made the same contention when they revealed a positive association between board size and the quality of financial statements. Similarly, Klai and Omri (2011) highlighted a positive association between financial reporting quality and board size. Akhtaruddin, Hossain, and Yao (2009) found a positive association between board size and voluntary disclosure. Large boards were related positively with earnings quality (Xie, Davidson, \& DaDalt's, 2003). In addition, large boards were shown to be more effective in overseeing a firm when compared to smaller boards based on Klein (2002).

Other studies supported a smaller board by contending that large board size is linked to low firm performance. Specifically, Yermack (1996) showed that smaller boards enhance the performance of the firm as the smaller number of members facilitate a unified unit and are more coordinated. Also, Xie et al. (2003) revealed that smaller boards offer superior financial reporting oversight and Bradbury, Mak, and Tan (2006) demonstrated that small boards are superior in terms of efficiency and effectiveness in observing and monitoring management. Moreover, Meca and Ballesta (2009) reported a negative board size-discretionary accruals relationship. Against this background, Dimitropoulos and Asteriou (2010) stated that among the many defects of a large board are miscommunication and lack of coordination between its members, which makes them less efficient in their oversight of management, compared to their smaller counterparts. Thus, based on previous results, the second hypothesis of this study will be as follows:

$\mathrm{H} 2$ : Board size is associated negatively with the timeliness of financial reports.

\subsubsection{CEO Duality}

CEO duality refers to the leadership structure wherein the executive officer also plays the role of the chairman of the board of directors (Abdelsalam \& Street, 2008). CEO duality is an issue that is of great importance to shareholders, lawmakers and regulators who would rather opt for separated roles of CEO and Chairman to guarantee board independence and effective corporate governance. As a CEO is overseen by the directors, it is of the former's interest to assume the function of chairman, but this often leads to conflicts of interest (Habib \& Hossain 2012). The presence of CEO duality facilitates the concentration of the power of decision-making in one individual, prevents the independence of the board, and lessens a board's capacity to carry out its role of monitoring (Mohamad-Nor et al., 2010).

According to agency theory, the positions of CEO and chairman should be granted to separate individuals as the responsibilities of the board is primarily to oversee and control management (Yonus, 2011). The agency theory also states that CEO duality might compromise the value and performance of the firm as this duality could prevent the board from properly monitoring the actions of the CEO (Habib \& Hossain 2012). The theory recommends separation of functions as this separation may result in more efficient monitoring. The opposite, which is CEO duality, could prevent the board from carrying out its oversight role. Similarly, according to Meca and Ballesta (2009), CEO duality indicates that less control may be exerted over the activities and behavior of management. The Jordanian Corporate Governance Code, consistent with the agency theory, recommends that separate individuals occupy the positions of chairman of the board and the CEO as the two positions entail different responsibilities. This separation prevents the occurrence of conflict of interests and leads to more effective supervision of management. The board may select one of the independent directors to be the chairman of the board.

Studies dedicated to CEO duality have provided mixed results. Abdelsalam and Street (2007) showed a 
relationship between timely Internet reporting and board of directors and suggested that corporate Internet reporting timeliness positively relates with the CEO. Similarly, Mohamad-Nor et al. (2010) reported that CEO duality leads to mitigating audit lag. Afify (2009), furthermore, found a positive association between CEO duality and lag of audit report indicating that CEO duality threatens quality monitoring and facilitates the withholding of undesirable information to external shareholders, which in turn increases audit report lag. Meanwhile, Abdullah (2006) confirmed the relationship between the separation between CEO and chairman roles, and that reporting timeliness in companies with non-executive chairman could promote corporate openness, and eventually, timely reporting. This can be explained by the fact that the separation is expected to offer higher incentives for a non-executive chairman to act in the shareholders' interests as opposed to a CEO's. Thus, based on the above findings, the third hypothesis is as follows:

H3: CEO duality is associated negatively with the timeliness of financial reports.

\subsubsection{Board Financial Expertise}

Board members accounting and financial expertise has also received attention from both media and regulators. The members' appropriate knowledge obtained through directorship experience could be significant in explaining the effectiveness of a particular board, and. hence, board members who lack experience are incapable of contributing fully to a firm's strategy (Kroll, Walters, \& Wright, 2008). Board experience will assist in creating transparent financial information as that experience facilitates a comparison of knowledge and experience with respect to other firms (Dahya, Lonie, \& Power, 1996). In this regard, Carpenter and Westphal (2001) reported that governance studies could stress a board's inclination to participate in decision control in considering whether directors have the correct experience to exercise control and to advice management. According to Agrawal and Chadha (2005), the rules assume that non-experienced members in the field of accounting and finance are not as capable of discerning problems in the reports, as are experienced members. On the other hand, experienced directors are capable of monitoring and advising because they positively contribute to company outcomes through experiential learning.

Prior studies dedicated to the examination of the effectiveness and efficiency of independent board directors have primarily related that experienced directors positively impact the quality of financial reporting. For instance, Agrawal and Chadha (2005) stated that the existence of independent expert members on a board help companies to steer clear of serious accounting issues that may force them to carry out earnings restatements. Stated clearly, independent directors possessing financial expertise are invaluable in overseeing the financial reporting practices of a firm. Similarly, Abdelsalam and Street (2007) reported a significant positive relationship between timeliness of financial reports and board experience with respect to the average age of directors. They added that more experienced directors use their expertise related to their advanced ages to oversee effectively management and to ensure timelier financial reports. Thus, the fourth hypothesis is as follows:

$\mathrm{H} 4$ : Board financial expertise is associated positively with the timeliness of financial reports.

\subsubsection{Board Diligence}

The Jordanian Corporate Governance Code suggests that the board of directors should have regular meetings (at least once in every quarter) to carry out effectively its roles and responsibilities and to rehash various issues relevant to the firm such as management and organizational performance. Board activity, proxied by frequency of board meeting, is a significant aspect of the operations of the board (Vafeas, 1999). Vafeas (1999) reported that high frequency of board meetings was often followed by enhanced operating performance. In a similar line of argument, Conger et al. (1998) demonstrated that board-meeting frequency is an essential resource that enhances the efficiency of a board of directors. On the other hand, Jensen (1993) showed that, in high performance companies, boards are relatively inactive with few conflicts. Such companies' boards routinely carry out their duties and functions and their role becomes increasingly important during crises when the shareholders' interests are in dire straits and when performance of the firm is low. In this case, boards are more capable of effectively dealing with problems. Meanwhile, Hashim and Rahman (2010) claimed that boards of directors who are more diligent are more concerned with the financial reporting aspects of the company.

Effectiveness of a board of directors is linked with the frequency of board meetings $(G r e c 0,2011)$ as the frequency of board meetings enhances the control level over the process of financial reporting (Carcello, Hermanson, Neal, \& Riley, 2002). Furthermore, Hashim and Rahman (2010) revealed that frequency of board meetings would facilitate reliance of auditors on a firm's strong internal controls and these strong controls would minimize the board's workload. Consequently, this efficiency would result in decreased the lag in audit reports. Contrastingly, Tauringana, Kyeyune, and Opio (2008) reported a significant negative relationship between board meeting frequency and timeliness of financial 
reports. Thus, we hypothesize that:

$\mathrm{H} 5$ : Board diligence is associated positively with the timeliness of financial reports.

\subsection{Audit committee}

According to Ika and Ghazali (2012), the relationship between the effectiveness of an audit committee and the timeliness of financial reports lies in the notion that an effective audit committee that diligently oversees financial reporting will impact the financial reporting quality which, in turn, will result in timely publication of financial information. They added that the effectiveness of the committee is a crucial factor that positively influences the timeliness of financial reports. Along the same line, Islam, Islam, Bhattacharjee, and Islam (2010) revealed that an audit committee is a mechanism that controls management incentive issues including the manipulation of financial statements to obtain the best rewards. In this regard, an effective audit committee enhances the quality and credibility of annual audited financial reporting. Also, an effective committee could guarantee the financial reporting, internal control and management risk reliability (DeZoort et al., 2002). Moreover, according to Boo and Sharma (2007), audit committees have a key positive role in resolving audit-management conflict and Goodwin and Seow (2002) revealed that an effective audit committee minimizes financial statement errors and maximizes the probability of detecting management fraud.

Furthermore, an audit committee is viewed as a sub-committee of the board of directors and that audit committee plays a key role in helping the board with establishing corporate governance and conducting other responsibilities. An audit committee is described as a committee of directors that is responsible to liaise with internal and external audit functions and to oversee external financial reporting (Gay \& Simnett, 2007). While the committee performs the majority of the main functions, the committee's main objective is overseeing the financial reporting process (Klein, 2002a). The audit committee is also referred to as a key institution in light of corporate governance as they assist the board in fulfilling their fiduciary and financial duties towards shareholders. The directors should develop a direct line of communication among themselves and external and internal auditors via audit committees (Abdullatif, 2010). However, Buchalter and Yokomoto (2003) supported the idea that the major objective of an audit committee is to ensure the accuracy of financial reports.

Among the many aims of the present study is to investigate the relationship between the audit committee presence and the timeliness of financial reports. An audit committee is generally viewed as a significant factor in the overall corporate governance structure of the firm, particularly in terms of audit quality and financial reporting oversight. Therefore, through its monitoring responsibilities, the audit committee is expected to provide feedback to management in order to generate timely financial information. Thus, based on the previous findings, the fifth hypothesis of this study is as follows:

H6: The presence of an audit committee is associated positively with the timeliness of financial reports.

\section{Methods}

Firms in Jordan are divided into three sectors: industrial, services, and financial sector. The sample for this study is Jordanian companies listed on the Amman Stock Exchange, excluding those in the financial sector. The financial sector is not included because this sector has special regulations pertaining to financial reporting, issued by the Jordan Central Bank and the Insurance Commission. Data was collected form a two-year period from 2011 and 2012. These years were selected because the implementation of the corporate governance policy in Jordan had just begun in 2009. Hair, Money, Samouel, and Page (2007) assert that some of the advantages of using secondary data are that it saves time and inexpensive to obtain. Secondary data provides the needed information on the effectiveness of corporate governance.

A multiple regression analysis was used to test the hypotheses, that is, to examine the association between board characteristics (i.e., board independence, board size, CEO duality, board financial expertise, board diligence and presence of audit committee) and the timeliness of financial reports. Multiple regression is a flexible method of data analysis that may be appropriate whenever a quantitative variable (the dependent variable) is to be examined in relation to any other factors (expressed as independent or predictor variables) (Cohen, Cohen, West, \& Aiken, 2003). We use two measures of timeliness: audit report lag (ARL) and management report lag (MRL). An audit report lag is the number of days from the financial year-end to the date the auditor signs the audit report. A management report lag is the number of days from the date the auditor signs the audit report to the date the company releases its financial report to the public.

The relationship between the independent variables and the dependent variables was analyzed by using the following two models.

Model 1 - Audit Report lag (ARL)

$A R L=\beta 0+\beta 1 B I N D$ it $+\beta 2 B S I Z$ it $+\beta 3 C E O$ it $+\beta 4 B D E L$ it $+\beta 5 B F E X$ it $+\beta 6 A C M$ it $\varepsilon$ 


\section{Model 2 - Management Report Lag (MRL)}

$M R L=\beta 0+\beta 1 B I N D$ it $+\beta 2 B S I Z$ it $+\beta 3 C E O$ it $+\beta 4 B D E L$ it $+\beta 5 B F E X$ it $+\beta 6 A C M$ it $+\varepsilon$ in Table 1.

The description of the above variables along with the expected direction and the related hypotheses are presented

Table 1: Definition of variables and measurements

\begin{tabular}{|c|c|c|c|}
\hline Variables & Definition of Variables & $\begin{array}{l}\text { Expected } \\
\text { Direction }\end{array}$ & $\begin{array}{c}\text { Relevant } \\
\text { Hypotheses }\end{array}$ \\
\hline \multicolumn{4}{|c|}{ Dependent Variables } \\
\hline$A R L=$ & $\begin{array}{l}\text { Audit report lags, measured by the number of days from the interval period of the financial } \\
\text { year end date to the date of signing the audit report. }\end{array}$ & --- & --- \\
\hline$M R L=$ & $\begin{array}{l}\text { Management report lags, measured by the difference between the time the auditor signs } \\
\text { the audit report and the company releases its financial report to the public. }\end{array}$ & --- & $--\cdot$ \\
\hline $\begin{array}{l}\text { Independent } \\
\text { Variables }\end{array}$ & Definition of Variables & $\begin{array}{l}\text { Expected } \\
\text { Direction }\end{array}$ & $\begin{array}{c}\text { Relevant } \\
\text { Hypotheses }\end{array}$ \\
\hline \multicolumn{4}{|c|}{ Board characteristics } \\
\hline $\mathrm{BIND}=$ & $\begin{array}{l}\text { Board independence, measured by ratio of non-executive directors to total number of } \\
\text { directors on the board. }\end{array}$ & + & $\mathrm{H}_{1}$ \\
\hline $\mathrm{BSIZ}=$ & Board Size, measured by total number of board directors. & - & $\mathrm{H}_{2}$ \\
\hline CEO = & CEO duality, measured by 1 if CEO-Chairman roles combine; 0 if separate. & - & $\mathrm{H}_{3}$ \\
\hline $\mathrm{BDEL}=$ & $\begin{array}{l}\text { Board diligence, measured by the number of board meetings held during the financial } \\
\text { year. }\end{array}$ & + & $\mathrm{H}_{4}$ \\
\hline BFEX $=$ & $\begin{array}{l}\text { Board Expertise, measured by proportion of board members with financial expertise to } \\
\text { total board members. }\end{array}$ & + & $\mathrm{H}_{5}$ \\
\hline $\mathrm{ACM}=$ & $\begin{array}{l}\text { Presence of audit committee, measured by a dummy variable, } 1 \text { if firm that has audit } \\
\text { committee and } 0 \text { otherwise. }\end{array}$ & + & $\mathrm{H} 6$ \\
\hline CTOR = & $\begin{array}{l}\text { Type of sector, classified into industrial or services sector, measured by dummy variable, } 1 \\
\text { if companies belong to an industrial sector, } 0 \text { otherwise }\end{array}$ & --口 & --- \\
\hline
\end{tabular}

\section{Results and Discussion}

Table 2 below presents the descriptive statistics of the dependent and independent variables, i.e., mean, minimum, maximum and standard deviation. This study used descriptive statistic method of research design in order to provide visions about the level of the corporate governance as well as the timeliness of financial reports in Jordanian listed firms. Hair et al. (2010) reported that descriptive approach is used to describe some situations or attributes by giving measures of a certain activity or event. The data were collected from 224 observations of industrial and services companies of the Amman Stock Exchange for a period from 2011 to 2012. For the dependent variable, this study used the audit report lag (ARL) model and the management report lag (MRL) model to measure the timeliness of financial reports. In relation to the audit report lag (ARL), the mean value for the audit report lag was 68.01 days with a maximum period of 271 days and minimum a period of 13 days. The mean value of the audit report lag in this study is somewhat similar to that of Al-Hija and Al-Hayek (2012) who found that the mean number of days to complete audit work in Jordanian-listed companies in 2010 was 60 days. Compared to other studies conducted in Arab countries, the audit report lag of Jordanian companies is better than that of the average lag of Egyptian companies (82 days) as reported by Abdelsalam and El-Masry (2008) but longer than the average of ARL in United Arab Emirates (43 days) as reported by Khasharmeh and Aljifri (2010). 
Table 2: Descriptive statistics for independent and dependent variables

\begin{tabular}{|c|c|c|c|c|c|}
\hline \multicolumn{6}{|c|}{ Descriptive Statistics } \\
\hline \multicolumn{6}{|c|}{$\begin{array}{c}\text { Panel A } \\
\text { Dependent Variables }\end{array}$} \\
\hline ARL & 224 & 13 & 271 & 68.01 & 29.930 \\
\hline MRL & 224 & 1 & 105 & 34.54 & 20.496 \\
\hline \multicolumn{6}{|c|}{$\begin{array}{c}\text { Panel B } \\
\text { Independent Variables }\end{array}$} \\
\hline BIND & 224 & .0 & 1.00 & 0.585 & 0.215 \\
\hline BSIZ & 224 & 3 & 14 & 8.47 & 2.362 \\
\hline CEO & 224 & 0 & 1 & 0.64 & 0.480 \\
\hline BDILIG & 224 & 4 & 12 & 7.71 & 1.630 \\
\hline BFEXP & 224 & .0 & .56 & 0.23 & 0.137 \\
\hline $\mathrm{ACM}$ & 224 & 0 & 1 & 0.59 & 0.492 \\
\hline SCTR & 224 & 0 & 1 & 0.46 & 0.500 \\
\hline
\end{tabular}

For the management report lag (MRL) model, the mean value of the management report lag was approximately 34.54 days with a minimum of 1 day and a maximum of 105 days. This result is inconsistent with prior studies by Nor and al Fadel (2006) who revealed that the average management report lag was 58 days in 2002 and 69 days in 2001. The difference in findings is probably to be due to the different period and samples used in the studies. In this study, the mean value of reporting lags was longer than that stated in a previous study by Zaitul (2010) who found that the mean value of management report lag among Indonesian firms was 19.8 days in 2008.

In terms of independent variables, the board independence (BIND) on average was $58.5 \%$. However, the maximum value was $100 \%$ and minimum value was $0 \%$, which implies that some boards of directors in Jordanian firms are completely independent and that some are not at all independent. The mean value of board size reported in this study was 8.47 members with a minimum of 3 and maximum of 14 . The mean number of board size in this study is consistent with a study that was conducted in Jordan by Jaafar and El-Shawa (2009), who found that the average of board size was 8.58 members. For the CEO duality, the results of descriptive statistics showed that the mean value of CEO duality was $64 \%$, which means that almost two-thirds of Jordanian firms had dual roles of CEO and chairman. This indicates that the Jordanian firms do not comply with requirements of the Corporate Governance Code, which states that the companies should separate the roles of CEO and chairman. In terms of board diligence, the results revealed that the average value of board diligence was $7.71 \%$ with a minimum of 4 and a maximum of 12 meetings. Moreover, financial expertise of boards on average was $23 \%$ with a minimum and a maximum value of $0 \%$ and $56 \%$ respectively.

Results indicated that 22 Jordanian firms did not have any financial expertise on their board of directors while 59\% of Jordanian firms studied had an audit committee. Overall, these results suggest that many of the firms studied did not align with the rules of the Jordanian Corporate Governance Code, which states the Jordanian firms should establish an audit committee to ensure the effective performance of the board of directors.

\subsection{Correlational Analysis}

The aim of the analysis is to discover if there were any problems of multicollinearity between the dependent and independent variables and association among variables of this study (Shukeri \& Nelson, 2011). Table 3 below shows Pearson correlation coefficients among the variables. In this study, all the correlation coefficients between the independent variables in the correlation matrix are less than 0.90 . This implies that multicollinearity is not a problem in the regression model. According to Hair et al. (2010) and Tabachnick and Fidell (2007), a multicollinearity problem occurs if the correlation among independent variables is above $(0.90)$. 
Table 3: Pearson correlation for the ARL and MRL models

\begin{tabular}{|c|c|c|c|c|c|c|c|c|}
\hline \multicolumn{9}{|c|}{ Correlations } \\
\hline $\begin{array}{l}A R L \\
A R L\end{array}$ & $\begin{array}{c}\mathrm{MRL} \\
1\end{array}$ & "BIND & בBSIZ & CEO & BDILIG & $\overline{~ B F E X P}$ & ACM & 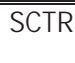 \\
\hline MRL & -.001 & 1 & & & & & & \\
\hline BIND & -.085 & -.024 & 1 & & & & & \\
\hline BSIZ & $.320^{* *}$ & $.167^{\star}$ & .020 & 1 & & & & \\
\hline CEO & $-.136^{*}$ & -.055 & .061 & . 061 & 1 & & & \\
\hline BDILIG & $-.159^{*}$ & $.182^{\text {t* }}$ & $-205^{* *}$ & . 016 & . 048 & 1 & & \\
\hline BFEXP & -.125 & -.001 & .070 & $-.207^{* *}$ & -.031 & -.003 & 1 & \\
\hline $\mathrm{ACM}$ & $-.192^{* *}$ & $-.301^{*+}$ & .056 & .041 & $.161^{*}$ & -.127 & -.103 & 1 \\
\hline SCTR & .010 & $.218^{\text {**x }}$ & -.050 & $.312^{* *}$ & -.016 & .103 & $-238^{* *}$ & .041 \\
\hline
\end{tabular}

Correlation is significant at the 0.01 level (2-tailed); ${ }^{*}$. Correlation is significant at the 0.05 level (2-tailed).

\subsection{Regression Analysis}

To test the hypotheses, a multiple regression analysis was used to examine the association between corporate governance and the timeliness of financial reports. This section discusses the results of the regression analysis between the independent variables and timeliness of financial reports of the two models (ARL and MRL). The results of regression analysis for ARL and MRL models are shown in Table 4 below.

In Table 4, the regression analysis shows that the $R^{2}$ for the ARL model was 0.221 . This shows that the variables of this study explain $22.1 \%$ of the variance of audit report lag. For the MRL model, the $\mathrm{R}^{2}$ for the MRL model was 0.174 , which indicates that the model is able to interpret $17.4 \%$ of the variability of the management report lag in Jordanian firms. The models of this study were significant; the ARL model was significant (F-statistic $=8.748, p<0.000$ ), the MRL model was also significant (F-statistic $=6.484, p<0.00$ ). This means that the models of this study (i.e., ARL and MRL) significantly describe the variations in the financial reports lag in Jordanian firms. The following section shows the results of the hypothesis testing and the relationship among the variables for both models (ARL and MRL).

Table 4: Regression Results: ARL and MRL Model

\begin{tabular}{|c|c|c|c|c|c|c|}
\hline \multicolumn{7}{|c|}{ Models of the study } \\
\hline & \multicolumn{3}{|c|}{ ARL } & \multicolumn{3}{|c|}{ MRL } \\
\hline Variables & Beta & t & Sig. & Beta & t & Sig. \\
\hline (Constant) & & 6.388 & .000 & & 1.485 & .139 \\
\hline BIND & -.112 & -1.812 & $.071^{*}$ & .024 & .383 & .702 \\
\hline BSIZ & .353 & 5.512 & $.000^{\star \star \star}$ & .127 & 1.929 & $.055^{\star \star}$ \\
\hline CEO & -.112 & -1.822 & $.070^{\star}$ & -.019 & -.308 & .759 \\
\hline BDILIG & -.199 & -3.189 & $.002^{\star \star \star}$ & .130 & 2.027 & $.044^{\star *}$ \\
\hline BFEX & -.094 & -1.498 & .136 & .038 & .592 & .555 \\
\hline $\mathrm{ACM}$ & -.213 & -3.442 & $.001^{\star \star \star}$ & -.291 & -4.574 & $.000^{\star \star *}$ \\
\hline SECTR & -.101 & -1.558 & .121 & .187 & 2.795 & $.006^{\star \star \star}$ \\
\hline \multicolumn{7}{|c|}{ Summary of the Regression Model } \\
\hline \multicolumn{2}{|c|}{ Dependent Variable: } & \multicolumn{2}{|c|}{$\overline{\mathrm{ARL}}$} & \multicolumn{3}{|c|}{ MRL } \\
\hline \multicolumn{2}{|c|}{$\mathrm{N}$} & \multicolumn{2}{|c|}{224} & \multicolumn{3}{|c|}{224} \\
\hline \multicolumn{2}{|c|}{ Adjusted R Square } & \multicolumn{2}{|c|}{.196} & \multicolumn{3}{|c|}{.147} \\
\hline \multicolumn{2}{|c|}{ R Square } & \multicolumn{2}{|c|}{.221} & \multicolumn{3}{|c|}{.174} \\
\hline \multicolumn{2}{|c|}{$\mathrm{F}$} & \multicolumn{2}{|c|}{8.748} & \multicolumn{3}{|c|}{6.484} \\
\hline \multicolumn{2}{|c|}{ Significant } & \multicolumn{2}{|c|}{.000} & \multicolumn{3}{|c|}{.000} \\
\hline
\end{tabular}

Note: ${ }^{* \star \star}$ Significant at the 0.01 level; ** Significant at the 0.05 level; * Significant at the 0.1 level.

As evidenced in Table 4 above, the result of regression analysis between board independence (BIND) and ARL model was significant and negative at $10 \%(t=-1.812, p=0.071)$. This means that the greater the percentage of board independence in firms would make audit report lag shorter. The result aligns with Afify (2009) and Zaitul (2010) who found that the greater the number of independent board members would make a shorter lag of audit report. However, the MRL model showed that no significant relationship between independence of board and management report lag $(\mathrm{t}=$ 
$0.383, p=0.702)$.

In relationship to the effect of board size on the timeliness of financial reports, the regression results revealed that the size of board had a significant positive effect on the audit report lag at $1 \%$ level $(t=5.512, p=0.000)$. Furthermore, the regression results for MRL model showed a significant and positive relationship at $5 \%$ level $(t=1.929, p=0.055)$. The positive and significant relationship means that the greater the number of board of directors would increase the audit and management report lag. The results of this current study reveal that the size of boards of directors is one essential factor that helps determine the level of timeliness of financial reports. This finding is consistent with Zaitul (2010) who found that small board size was statistically significant with respect to the timeliness of financial reports.

The relationship between CEO duality and ARL model is negative as predicted but slightly significant at $10 \%$ level $(t=-1.822, p=0.070)$. This finding implies that the firms that separated the roles of CEO and chairman were faster in issuing financial reports than the firms that had dual rules of CEO and chairman. The results of this study support the agency theory, which states that, for firms separating the roles of chief executive officer and chairman, there is a greater supervisory role of these individuals, therefore improving the publication of financial reports in a timely manner. In other words, the results of this current support the argument that firms can improve the timeliness of financial reports through effective and efficient segregation of tasks and duties, by separating between the roles of chief executive officer and chairman. However, the findings of MRL model did not show a significant relationship between CEO and management report lag $(t=-0.308, p=0.759)$.

As for the relationship between board diligence and timeliness of financial reports, the results of ARL model show that diligence of boards had a significant and negative effect on audit report lag $(t=-3.189, p=0.002)$. This result supports the argument that the higher number of board of directors meetings would reduce the audit report lag and thus improving the timeliness of financial reports. However, the results of MRL model shows that a positive relationship between board diligence and management report lag at the $5 \%$ level $(t=2.027, p=0.044)$. In other words, the greater the number of the board meetings would mean that the management of firms took more time to release the financial report to the public.

The results of board financial expertise were contradictory to expectations and indicated that the financial expertise of the board of directors did not influence the timeliness of financial reports for both the ARL and MRL models. This result is consistent with Hashim and Rahman (2010) who found an insignificant relationship between board financial expertise and timeliness of financial reports.

Consistent with expectations, this study found a significant and negative relationship between presence of audit committee and timeliness of financial reports for both the ARL and MRL models. The results of this study suggest that the firms that have audit committee are associated with a lower financial reporting lag that will lead to improve timeliness of financial report. The result of the current study aligns with the notion that the presence of audit committee will lead to better control and ensure the effective performance of the board of directors (Boo \& Sharma, 2007; DeZoort et al., 2002; Gay \& Simnett, 2007; Goodwin \& Seow, 2002; Islam et al., 2010). In other words, an efficient and effective audit committee plays a central role in improving the quality of financial reporting in terms of timeliness. This result is consistent with those of previous researchers who found that the presence of audit committee plays an important role in ensuring communication between external auditors and management of companies and organization in number of audit hours of the external auditors, and thus would improve timeliness of financial reports through reduced financial reporting lag (Afify, 2009).

In addition, the statistical results of this study also show a substantial variance in the timeliness of annual financial reports between sectors in Jordan. As shown in Table 4, a significant positive relationship exists between the type of sector (SCTR) and management report lag $(t=2.795, p=0.006)$ suggesting that firms in the service sector take less time to publish their financial reports than those in the industrial sector.

\section{Conclusion}

Timeliness of financial reports is a pivotal issue owing to the impact of the lag on several relevant parties. We investigate the influence of corporate governance mechanisms (i.e., board independence, board size, CEO duality, board diligence, board financial expertise and the presence of audit committee) as well as types of sector on the timeliness of financial reports among Jordanian listed firms. The findings of the study support the agency theory, in that the results of the relationships between the corporate governance mechanisms and that ARL and MRL were generally significant. This indicates that the corporate governance mechanisms play an important role in reducing financial reporting lag behaviour, which would lead to improved timeliness of financial reports. Consistent with most other studies, the results show that corporate governance mechanisms affect the timeliness of financial reports. Specifically, board independence, board 
size, CEO duality, board diligence and the presence of an audit committee are significantly related to ARL. Further, board size, board diligence duality and presence of audit committee are significantly related to MRL. In general, this study concludes that companies with effective internal mechanisms for corporate governance have timelier financial reporting. These findings support the argument that board independence, board size, CEO duality board diligence and presence of audit committee are important determinants of the timeliness of financial reports. This study serves as valuable input for policy makers and regulators in formulating policies and strategies with respect to the timeliness of financial reports in Jordan.

On the whole, the present study has contributed to the field of financial reporting with respect to lag-related studies, specifically with regard to determinants of timeliness of financial reports in the Jordanian context. We fervently hope that the study has created new opportunities for future studies to examine the timeliness in other countries in which this topic of research is absent. Moreover, this study also provides opportunities for more extensive studies concerning the topic in the future. Our results are invaluable to investors, legislators and decision-makers. They show the critical importance of the gap between the Companies Controlling Department's (CCD) requirements and the requirements laid down by the Jordanian Securities Commission (JSC) on one hand, and firms that have the tendency to delay submission of their financial reports on the other hand.

\section{Acknowledgment}

Thank you to Universiti Utara Malaysia for funding this research.

\section{References}

Abdelsalam, O. H., \& Street, D. L. (2007). Corporate governance and the timeliness of corporate internet reporting by UK listed companies. Journal of International Accounting, Auditing and Taxation, 16(2), 111-130.

Abdelsalam, O., \& El-Masry, A. (2008). The impact of board independence and ownership structure on the timeliness of corporate internet reporting of Irish-listed companies. Managerial Finance, 34(12), 907-918.

Abdullah, S. N. (2006). Board composition, audit committee and timeliness of corporate financial reporting in Malaysia. Corporate ownership \& control, 4(2), 33-45.

Abdullatif, M. (2010). The effectiveness of audit committees in Jordanian public shareholding companies and potential company characteristics affecting it: perceptions from auditors in Jordan. Dirasat: Administrative Sciences, 33(2).

Abed, S., Al-Attar, A., \& Suwaidan, M. (2012). Corporate governance and earnings management: Jordanian evidence. International Business Research, 5(1), 216-225.

Afify, H. A. E. (2009). Determinants of audit report lag: Does implementing corporate governance have any impact? Empirical evidence from Egypt. Journal of Applied Accounting Research, 10(1), 56-86.

Agrawal, A., \& Chadha, S. (2005). Corporate governance and accounting scandals. Journal of Law and Economics, 48(2), 371-406.

Ajinkya, B., Bhorjraj, S., \& Sengupta, P. (2005). The association between outside directors, institutional investors, and the properties of management earnings forecasts. Journal of Accounting Research, 43(3), 343-376.

Akhtaruddin, M., Hossain, M. A., Hossain, M., \& Yao, L. (2009). Corporate governance and voluntary disclosure in corporate annual reports of Malaysian listed firms. Journal of Applied Management Accounting Research, 7(1), 1-19.

Aktas, R. and M. Kargýn (2011) Timeliness of reporting and the quality of financial information. International Research Journal of Finance and Economics ISSN 1450-2887(63), 71-77.

Al-Ajmi, J. (2008). Audit and reporting delays: Evidence from an emerging market. Advances in Accounting, 24(2), 217-226.

Al-Hija, M. A. and A. Al-Hayek (2012). Characteristics of audit committees and their impact on the audit report lag: an empirical study on the Jordanian public companies. Journal of the Islamic University of Economics Studies and Management, 20(2), 439-463.

Al-Khouri, R. S. \& M. M. Balqasem (2006). The effect of timing of financial statements disclosure on stock prices and trading volume (an empirical study on amman stock exchange). Jordan Journal of Business Administration, 2(2),163-186.

Al-Tahat, S. S. Y. (2010). The Timeliness and Extent of Disclosure of Corporate Interim Financial Reporting in Jordan (Doctoral dissertation), College of Business, Universiti Utara Malaysia.

Beasley, M. S., \& Petroni, K. R. (2001). Board independence and audit-firm type. Auditing: A Journal of Practice \& Theory, 20(1), 97114.

Berg, A., \& Nenova, T. (2004), 'Report on the Observance of Standards and Codes (ROSC): Corporate Governance Country Assessment-Jordan', World Bank-

Boo, E. F., \& Sharma, D. (2008). Effect of regulatory oversight on the association between internal governance characteristics and audit fees. Accounting \& Finance, 48(1), 51-71.

Bradbury, M., Mak, Y. T., \& Tan, S. M. (2006). Board characteristics, audit committee characteristics and abnormal accruals. Pacific Accounting Review, 18(2), 47-68.

Braswell, M., Daniels, R. B., Landis, M., \& Chang, C. C. A. (2012). Characteristics Of Diligent Audit Committees. Journal of Business \& Economics Research (JBER), 10(4), 191-206. 
Brown, P., Dobbie, G. W., \& Jackson, A. B. (2011). Measures of the timeliness of earnings. Australian Accounting Review, 21(3), 222234.

Buchalter, S., and K. Yokomoto. (2003). Audit committees' responsibilities and liability. The CPA Journal, 73 (3), 18-24.

Carcello, J. V., Hermanson, D. R., Neal, T. L., \& Riley, R. A. (2002). Board characteristics and audit fees. Contemporary Accounting Research, 19(3), 365-384.

Carpenter, M. A., \& Westphal, J. D. (2001). The strategic context of external network ties: examining the impact of director appointments on board involvement in strategic decision making. Academy Of Management Journal, 44(4), 639-660.

Chambers, A. E., \& Penman, S. H. (1984). Timeliness of reporting and the stock price reaction to earnings announcements. Journal of Accounting Research, 22(1), 21-47.

Cheng, E. C. M., \& Courtenay, S. M. (2006). Board composition, regulatory regime and voluntary disclosure. The International Journal of Accounting, 41(3), 262-289.

Chiang, H. T., \& Chia, F. (2005). An empirical study of corporate governance and corporate performance. Journal of American Academy of Business, 6(1), 95-101.

Cohen, J., Cohen, P., West, S. G., \& Aiken, L. S. (2003). Applied multiple regression/correlation analysis for the behavioral sciences, 3rd Ed. Mahwah, NJ: Lawrence Erlbaum Associates.

Conger, J. A., Finegold, D., \& Lawler, E. E. (1998). Appraising boardroom performance Harvard Business Review, 76, $136-164$.

Dahya, J., Lonie, A. A., \& Power, D. M. (1996). The case for separating the roles of chairman and CEO: An analysis of stock market and accounting data. Corporate Governance: An International Review, 4(2), 71-77.

DeZoort, F. T., Hermanson, D. R., Archambeault, D. S., \& Reed, S. A. (2002). Audit Committee effectiveness: a synthesis of the empirical Audit Committee Literature. Journal of Accounting Literature, 21, 38-75.

Dimitropoulos, P. E., \& Asteriou, D. (2010). The effect of board composition on the informativeness and quality of annual earnings: Empirical evidence from Greece. Research in International Business and Finance, 24(2), 773-784.

Errunza, V. R., \& Losq, E. (1985). The behavior of stock prices on LDC markets. Journal of Banking \& Finance, 9(4), 561-575.

Fama, E. F., \& Jensen, M. C. (1983). Separation of ownership and control. Journal of law and economics, 26(2), 301-325.

Financial Accounting Standards Board. FASB (1980). Statement of Financial Accounting Concepts No. 2: Qualitative Characteristics of Accounting Information.

Gay, G. and Simnett, R. (2007), Auditing and Assurance Services in Australia, McGraw-Hill Irwin,

Givoly, D., \& Palmon, D. (1982). Timeliness of annual earnings announcements: Some empirical evidence. Accounting Review, 57(3) .486-508.

Goodwin, J., \& Seow, J. L. (2002). The influence of corporate governance mechanisms on the quality of financial reporting and auditing: Perceptions of auditors and directors in Singapore. Accounting \& Finance, 42(3), 195-223.

Greco, G. (2011). Determinants of board and audit committee meeting frequency: Evidence from Italian companies. Managerial Auditing Journal,26(3),208-229.

Habib, A., \& Hossain, M. (2012). CEOs and accounting information: A review of the literature .Paper presented at the International Conference on Excellence in Business. Sharjah, United Arab Emirates.

Hair, J. F., Black, W. C., Babin, B. J., Anderson, R. E., \& Latham, R. (2010). Multivariate data analysis (7th ed). New Jersey: Pearson3.

Hair, J., Money, J. A. H., Samouel, P., \& Page, M. (2007). Research methods for business (6th ed.). Australia: John Willey \& Sons3.

Hashim, U. J. B., \& Rahman, R. B. A. (2010). Board independence, board diligence, board expertise and impact on audit report lag in Malaysian market. Finance and Corporate Governance Conference 2011 Paper. Retrieved from http://ssrn.com/abstract= 1717479

Haw, I. M., Qi, D., \& Wu, W. (2000). Timeliness of annual report releases and market reaction to earnings announcements in an emerging capital market: The case of China. Journal of International Financial Management \& Accounting, 11(2), 108-131. http://epublications.bond.edu.au/cgi/viewcontent.cgi?article=1033\&context=theses

Ika, S. R., \& Ghazali, N. A. M. (2012). Audit committee effectiveness and timeliness of reporting: Indonesian evidence. Managerial Auditing Journal, 27(4), 403-424.

Islam, M. Z., Islam, M. N., Bhattacharjee, S., \& Islam, A. Z. (2010). Agency Problem and the Role of Audit Committee: Implications for Corporate Sector in Bangladesh. International Journal of Economics and Finance, 2(3), P177.

Jaafar, A., \& El-Shawa, M. (2009). Ownership concentration, board characteristics and performance: evidence from Jordan. Accounting in Emerging Economies (Research in Accounting in Emerging Economies, Volume 9), Emerald Group Publishing Limited, 9, 7395.

Jensen, M. C. (1993). The modern industrial revolution, exit, and the failure of internal control systems. The Journal of Finance, 48(3), 831-880.

John, K., \& Senbet, L. W. (1998). Corporate governance and board effectiveness. Journal of Banking \& Finance, 22(4), $371-403$.

Khasharmeh, H. A., \& Aljifri, K. (2010). The timeliness of annual reports in Bahrain and the United Arab Emirates: An empirical comparative study. The International Journal Of Business And Finance Research, 4(1), 51-72.

Klai, N., \& Omri, A. (2011). Corporate governance and financial reporting quality: The case of Tunisian firms. International Business Research, 4(1), 158-1663.

Klein, A. (2002a). Audit committee, board of director characteristics, and earnings management. Journal of Accounting and Economics, 33(3), 375-400.

Kroll, M., Walters, B. A., \& Wright, P. (2008). Board vigilance, director experience, and corporate outcomes. Strategic Management 
Journal, 29(4), 363-382.

Ku Ismail, K., \& Chandler, R. (2004). The timeliness of quarterly financial reports of companies in Malaysia. Asian Review of Accounting, 12(1), 1-18.

Leventis, S., Weetman, P., \& Caramanis, C. (2005). Determinants of audit report lag: Some evidence from the Athens Stock Exchange. International Journal of Auditing, 9(1), 45-58.

Lipton, M., \& Lorsch, J. W. (1992). A Modest Proposal for Improved Corporate Governance .Business Lawyer, 48.(1).

Matoussi, H., \& Chakroun, R. (2008). Board composition, ownership structure and voluntary disclosure in annual reports: Evidence from Tunisia. Laboratoire Interdisciplinaire de Gestion Universite-Entreprise (LIGUE), 1-28.

Meca, E. G., \& Ballesta, J. P. S. (2009). Corporate governance and earnings management: A meta-analysis. Corporate Governance: An International Review, 17(5), 594-6103.

Mohamad-Nor, M. N., Shafie, R., \& Wan-Hussin, W. N. (2010). Corporate governance and audit report lag in Malaysia. Asian Academy of Management Journal of Accounting and Finance (AAMJAF), 6(2), 57-84.

Nour, A. N. I., \& Al-Fadel, M. M. (2006). Analysis of the importance of the factors that affected the delay of issuing corporate annual reports: comparison study between views of corporate managers and auditors in Iraq and Jordan. Jordan Journal of Business Administration, (2), 33.

Owusu-Ansah, S. (2000). Timeliness of corporate financial reporting in emerging capital markets: Empirical evidence from the Zimbabwe Stock Exchange. Accounting and business research, 30(3), 241-254.

Peasnell, K. V., Pope, P. F., \& Young, S. (2005). Board monitoring and earnings management: do outside directors influence abnormal accruals?. Journal of Business Finance \& Accounting, 32(7-8), 1311-1346.

Sanda, A., Garba, T., \& Mikailu, A. S. (2011). Board independence and firm financial performance: evidence from Nigeria (No. RP_213). African Economic Research Consortium. In proceeding of the Centre for the Study of African Economies (CSAE) for presentation at the CSAE Conference 2008 titled Economic Development in Africa at St Catherine's College, University of Oxford, Oxford, 1618 March 2008. Retrieved from: http:/leconpapers.repec.org/paper/aerrpaper/rp_5f213.htm.

Sharar, Z. (2006). A Comparative Analysis of the Corporate Governance Legislative Frameworks in Australia and Jordan Measured against the OECD Principles of Corporate Governance 2004 as an International Benchmark( (Doctoral dissertation, School of Law, Bond university,. Australia) Retrieved from:

Shukeri, S. N., \& Islam, M. A. (2012). The determinants of audit timeliness: Evidence from Malaysia. Journal of Applied Sciences Research, 8(7).

Shukeri, S. N., \& Nelson, S. (2011). Timeliness of Annual Audit Report: Some Empirical Evidence from Malaysia. Paper presented at the Entrepreneurship and Management International Conference (EMIC 2) Kangar, Perlis Malaysia. Retrieved from http://ssrn.com/abstract=1967284.

Tabachnick, B.G. \& Fidell, L.S (2007). Using multivariate statistics (5th ed). Boston: Pearson Education.

Tauringana, V., Kyeyune, M. F., \& Opio, P. J. (2009). Corporate governance, dual language reporting and the timeliness of annual reports on the Nairobi stock exchange. Research in Accounting in Emerging Economies, 8, 13-37.

Vafeas, N. (1999). Board meeting frequency and firm performance. Journal of Financial Economics, 53(1), 113-142.

Wu, C., Wu, C. S., \& Liu, V. W. (2008). The release timing of annual reports and board characteristics. The International Journal of Business and Finance Research, 2(1), 103-108.

Xie, B., Davidson, W. N., \& DaDalt, P. J. (2003). Earnings management and corporate governance: the role of the board and the audit committee. Journal of corporate finance, 9(3), 295-316.

Yermack, D. (1996). Higher market valuation of companies with a small board of directors. Journal of financial economics, 40(2), 185211.

Zaitul. (2010). Board of Directors, audit committee, auditor characteristics and the timeliness of financial reporting in listed companies in Indonesia (Doctoral dissertation, College of business, University Utara Malaysia) Retrieved from http://www.uum.edu.my. 